\title{
Mathematical Modeling of Double-Skin Facade in Northern Area of China
}

\author{
Zou Huifen, ${ }^{1}$ Fei Yingchao, ${ }^{1}$ Yang Fuhua, ${ }^{1}$ Tang Hao, ${ }^{1}$ Zhang Ying, ${ }^{1}$ and Ye Sheng ${ }^{2}$ \\ ${ }^{1}$ School of Municipal and Environment Engineering, Shenyang Jianzhu University, Shenyang 110168, China \\ ${ }^{2}$ Management School, Shenyang Jianzhu University, Shenyang 110168, China \\ Correspondence should be addressed to Fei Yingchao; ser478953481@126.com
}

Received 26 October 2012; Revised 9 January 2013; Accepted 9 January 2013

Academic Editor: Zhijun Zhang

Copyright (C) 2013 Zou Huifen et al. This is an open access article distributed under the Creative Commons Attribution License, which permits unrestricted use, distribution, and reproduction in any medium, provided the original work is properly cited.

This paper focuses on the operation principles of the double-skin facade (DSF) in winter of severe cold area. The paper discussed the main influence factors of building energy consumption, including the heat storage cavity spacing, the air circulation mode, the building envelope, and the building orientation. First, we studied the relationship among the thermal storage cavity spacing, the temperature distribution in the cavity of the DSF, and the indoor temperature. Then, we discussed the influence on the ambient temperature in the building exerted by the air circulation system of the double-skin facade. Finally, we analyzed the influence on the whole building energy consumption of the DSF buildings under the situation of different building envelopes and different building orientations. Based on the results of the numerical simulation, the paper put forward an operation strategy analysis of the DSF buildings in severe cold area, in order to achieve the purpose of building energy saving.

\section{Introduction}

Modern architecture is dominated by transparent buildings. The large glazed areas result in high building heating and cooling loads, leading to high levels of energy consumption and therefore significant financial and environmental burdens. The double-skin facade is one potential response to these problems. On the other hand, in both developed and developing countries, building energy consumption accounts a large part in the total world energy consumption. All the countries around the world put the building energy-saving as the focus of their work [1]. Architects have long been hoping to decrease the building energy consumption and make the shape of the building more beautiful and unique through the application of glass curtain wall in the meanwhile. Thus research on the thermophysical properties of the glass curtain wall has become a hot spot. The paper studied the energysaving properties of the DSF in severe cold area based on the winter weather conditions of Shenyang, respectively, using the flow field simulation software FLUENT and the building energy simulation software DEST to analyze temperature characteristics and building energy consumption of the double-skin facade.

\section{Thermal Properties of the Double Skin Facade}

The structure of the DSF is shown in Figure 1. The main factors driving airflow within the cavity are buoyancy and wind pressure [2]. The pressure differences resulting from these forces can be determined with the equations below, respectively:

$$
\Delta p_{\text {buoyancy }}=\rho_{\mathrm{o}} g H\left(\frac{T_{\mathrm{cav}}}{T_{e}}-1\right)(P a),
$$

where $\rho_{o}$ is the outdoor air density $\left(\mathrm{kg} / \mathrm{m}^{3}\right), g$ is gravitational acceleration $\left(9.8 \mathrm{~m} / \mathrm{s}^{2}\right), H$ is the cavity height $(\mathrm{m}), T_{\text {cav }}$ is the average cavity temperature, and $T_{e}$ is the outdoor air temperature;

$$
\Delta P_{\mathrm{wind}}=\frac{\rho_{o} U_{\mathrm{met}}^{2}}{h_{\mathrm{met}}}\left(\frac{\delta_{\mathrm{met}}}{h_{\mathrm{met}}}\right)^{2 a_{\mathrm{met}}}\left[h^{2 a}-(h+H)^{2 a}\right](p a),
$$

where $U_{\text {met }}$ is the measured wind speed at height $h_{\text {met }}$, $\delta_{\text {met }}$ is the wind boundary layer thickness, $a$ is the ASHRAE local terrain exponent, $h$ is the height of the lower cavity opening, 


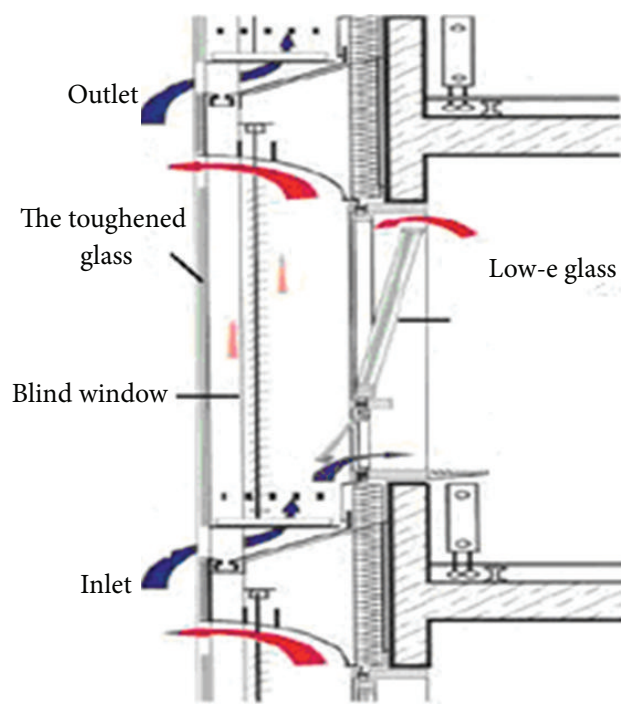

Figure 1: The structure of DSF.

and $H$ is the distance between inlet and outlet openings. The airflow rate through the cavity can be determined by

$$
V=a \Delta P^{b} \quad \mathrm{~m}^{3} / \mathrm{hr}
$$

where $a$ and $b$ are pressure loss characteristics of the cavity and openings. In a summer condition, the DSF can exploit the chimney effect formed in the cavity-taking away the indoor heat through natural ventilation and reducing the indoor temperature. In winter condition, the DSF needs to exploit as much solar radiation as possible to form the greenhouse effect in the cavity which will improve the insulation effect of the cavity and reduce the heating energy consumption.

The DSF is a special 3-layer glass curtain wall system. Under the condition of no ventilation in winter, the forms of heat transfer in the air layer between heating storage of the glass curtain include convective heat transfer, radiation heat transfer and thermal conductivity [3]. The calculation formula for heat transfer coefficient $K$ of common glass curtain wall is

$$
K=\left(\frac{1}{h_{e}}+\frac{\delta}{\lambda}+\frac{1}{h_{m}}\right)^{-1}
$$

where $K$ is the heat transfer coefficient $K$ of common glass curtain wall; $h_{e}$ and $h_{m}$ the surface heat transfer coefficients of the outdoor side and the indoor side, $\mathrm{w} /\left(\mathrm{m}^{2} \cdot \mathrm{K}\right) ; \lambda$ the thermal conductivity of the glass, $\mathrm{w} /\left(\mathrm{m}^{2} \cdot \mathrm{K}\right) ; \delta$ the thickness of the glass.

The calculation formula for surface heat transfer coefficient of the outdoor side $h_{e}$ is

$$
h_{e}=10.0+4.1 v
$$

where $v$ is the outdoor wind speed $(\mathrm{m} / \mathrm{s})$.

In accordance with the standard above, when comparing the heat transfer of the glass, we set $h_{e}$ as $23 \mathrm{w} /\left(\mathrm{m}^{2} \cdot \mathrm{K}\right)$ when the outdoor wind speed is $3 \mathrm{~m} / \mathrm{s}$. And the calculation formula for surface heat transfer coefficient of the indoor side $h_{\text {in }}$ is

$$
h_{\text {in }}=3.6+\frac{4.4 \varepsilon}{0.83}
$$

where $\varepsilon$ is the Emission rate of the indoor side and the indoor side of the DSF is ordinary transparent glass, which will be taken as $0.83, h_{\text {in }}=8.0$. Thermal conductivity of the ordinary toughened glass is $0.76 \mathrm{w} /\left(\mathrm{m}^{2} \cdot \mathrm{K}\right)$, when the thickness of the glass is $6 \mathrm{~mm}$, and the glass thermal resistance is $0.008 \mathrm{w} /\left(\mathrm{m}^{2} \cdot \mathrm{K}\right)$. According to the calculation formula above, we can get heat transfer coefficient of $6 \mathrm{~mm}$ thick ordinary toughened glass is $6.16 \mathrm{w} /\left(\mathrm{m}^{2} \cdot \mathrm{K}\right)$. Similarly we can compute out that heat transfer coefficient of the $24 \mathrm{~mm}$ thick Low-e insulating glass is $1.76 \mathrm{w} /\left(\mathrm{m}^{2} \cdot \mathrm{K}\right)$. In the setting of FLUENT material properties, all the glasses are set to translucent transmission medium [4].

\section{CFD Numerical Simulations}

Building indoor thermal environment in severe cold area is mainly influenced by the combined effect of thermal environment, wet environment, the air environment of the microclimate, and the atmospheric environment. These effects either directly or indirectly cause a certain degree of influence on the building indoor environment [5]. In severe cold area, the design of the building envelope, especially the thermal design for adaptive glass curtain wall, has its own characteristics [6], which is different from the other thermal design areas in China. The severe cold area mainly controls the indicator of envelope insulation and generally does not take summer heat insulation into consideration. We will use the software FLUENT to explore the relationship among different spacing values of the heat storage cavity, different gas circulation systems, the temperature in the cavity of the double-skin facade, and the indoor temperature.

\subsection{Simulation about Influence of the Heat Storage Cavity Spacing on Thermal Performance of the DSF}

3.1.1. Selection of the CFD Model. The model of the doubleskin facade uses the single outer layer of $6 \mathrm{~mm}$ thick toughened glass and the inner layer of $6 \mathrm{~mm}+12 \mathrm{~mm}+6 \mathrm{~mm}$ Lowe hollow glass. This model consists of DSF and indoor room. The structure size (length $\times$ height) of the DSF is $3 \mathrm{~m} \times 4 \mathrm{~m}$, and indoor room (length $\times$ width $\times$ height) is $2.4 \mathrm{~m} \times 3 \mathrm{~m} \times$ $4 \mathrm{~m}$. The model, respectively, takes $0.2 \mathrm{~m}, 0.4 \mathrm{~m}$, and $0.6 \mathrm{~m}$, as the cavity spacing value. Figure 2 shows the geometric model established by GAMBIT when the cavity spacing is $0.4 \mathrm{~m}$.

This subject is mainly to simulate the flow state of the airflow inside the DSF and the influence on airflow in the room which is exerted by curtain wall. The airflow inside the channel of DSF is a heat and mass transfer problem, so we adopt RNG $k-\varepsilon$ turbulent model and DO radiation model in the research. Hypothesis Boussinesq is used to make the processing of the buoyancy lift items produced by temperature differ easier [7]. Select the climate characteristic of Shenyang prefecture as the research object, Shenyang: 


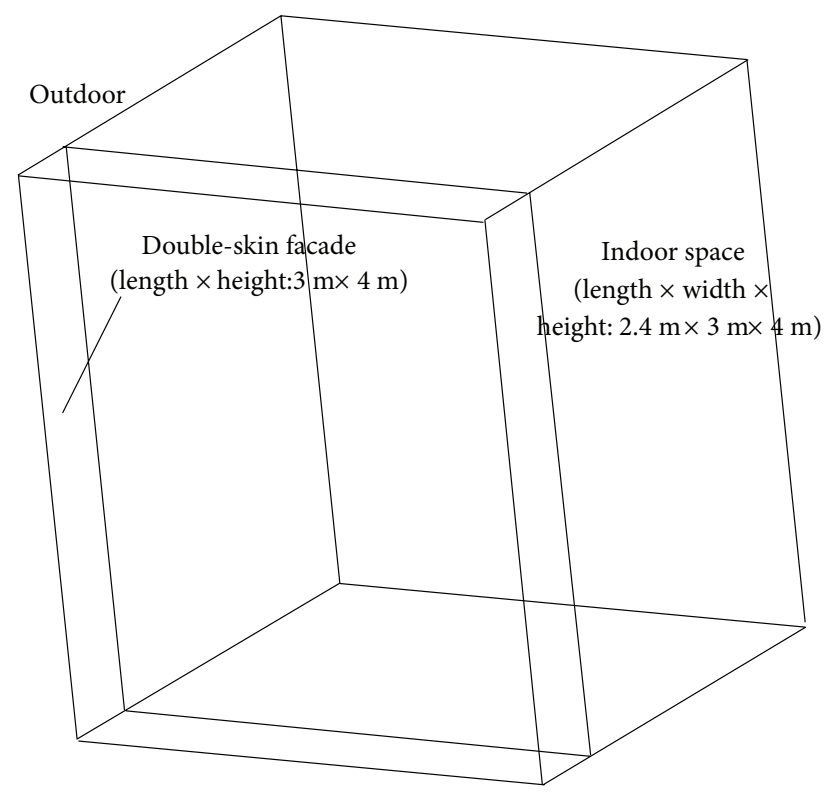

FIgURE 2: The geometric model.

northern latitude $41.8^{\circ}$ and east longitude $123.38^{\circ}$, in the east eighth zone. According to the Heating and Ventilation Design Specification. The designed indoor comfort conditions are as follows: temperature: $18 \sim 22^{\circ} \mathrm{C}$; relative humidity: $40 \% \sim 60 \%$; wind speed should not be more than $0.2 \mathrm{~m} / \mathrm{s}$; the solar radiation of winter solstice in Shenyang was shown in Table 1.

3.1.2. Simulation Results Analysis. In winter condition, the DSF generally uses a closed and no-cyclic form, in order to form greenhouse effect and to improve the indoor temperature [8]. The subject selects the main time on the winter solstice to have the simulation, for on the day, we can accept solar radiation of shortest duration during the daytime. Under this condition and when thermal channel spacing, respectively, choose $200 \mathrm{~mm}, 400 \mathrm{~mm}, 600 \mathrm{~mm}$, simulate the temperature in the thermal channels and the changes of indoor temperature. We use FLUENT to stimulate these 27 examples, respectively, and the simulation results are shown in Figures 4 and 5. With reference to the change curve of solar radiation in the winter solstice day (Figure 3), solar radiation is an important parameter which affects the temperature of the cavity and the indoor temperature, and the changes of cavity temperature and indoor temperature are in proportion to changes of the solar radiation.

Figure 4 shows that during the daytime in the winter the temperature of DSF with three different spacing value in the cavity is obviously higher than that of the outdoor temperature; exactly the maximum temperature difference between temperature in the cavity and the outdoor temperature can be up to $26^{\circ} \mathrm{C}$. Visibly the effect of the greenhouse is very significant, which can play a role in improving the cavity temperature. Meanwhile during the daytime in the winter the larger cavity spacing will be conducive to gain more solar

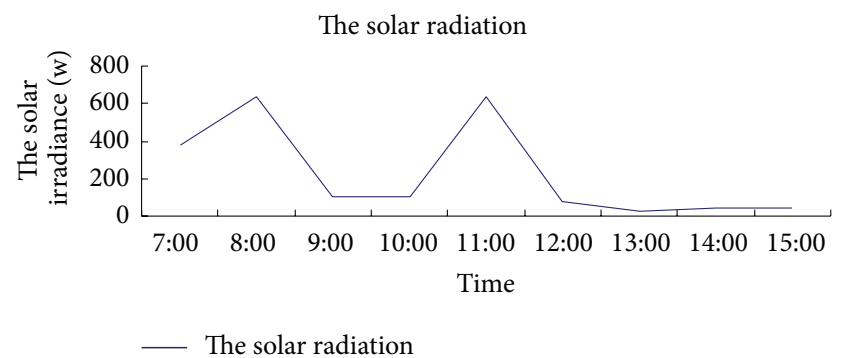

FIGURE 3: The solar radiation of the winter solstice.

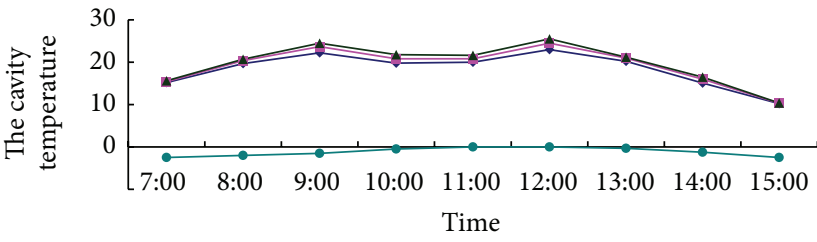

- The cavity spacing is $200 \mathrm{~mm}$

$\ldots$ The cavity spacing is $600 \mathrm{~mm}$

$\rightarrow$ The cavity spacing is $400 \mathrm{~mm}$

- The outdoor-bulb temperature

FIGURE 4: The interior temperature distributions when the cavity spacing of DSF is different.

radiation heat, which will come out with a positive effect on improving the cavity temperature.

As shown in Figure 5, similar to the change rules of cavity temperature, the changes of indoor temperature are consistent with changes of solar radiation. When the solar radiation arrives at maximum value, the indoor temperature gets to the maximum; when the solar radiation gradually decreases, the cavity temperature reduces gradually. But double-skin facade of short cavity spacing is conducive to extend the exothermic time from the interior and cavity to the outside. So in a short period of time, solar radiation can play the role of thermal insulation.

\section{Simulation about the Influence of Gas Circulation Mode on the Thermal Performance of the Double-Skin Facade}

In severe cold area, it is usual to adopt the double-skin facade of external cycle in the summer [9]. To make full use of solar radiation to reach the greenhouse effect in winter, we generally close the air inlet and outlet on the inner side of the south DSF. Under the action of direct sunlight, there will be a closed greenhouse in the cavity with a high temperature so that the heat dissipation from interior to outer environment will be reduced. But generally the north double-skin facade cannot get enough direct sunlight. In order to increase the thermal resistance of heat storage cavity effectively and reduce the indoor heat loss, the general approach is sending the indoor exhaust through the delivery outlet which is on the indoor side to the cavity, and then discharging the exhaust from the air outlet on the upper side of the cavity 


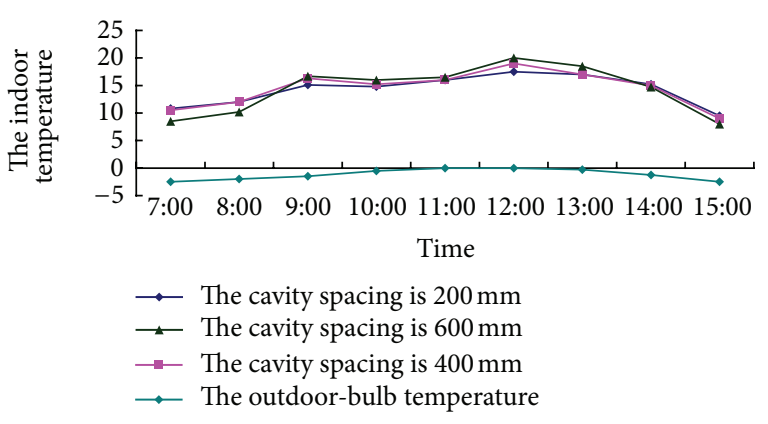

FIgURE 5: The room temperature distributions when the cavity spacing of DSF is different.

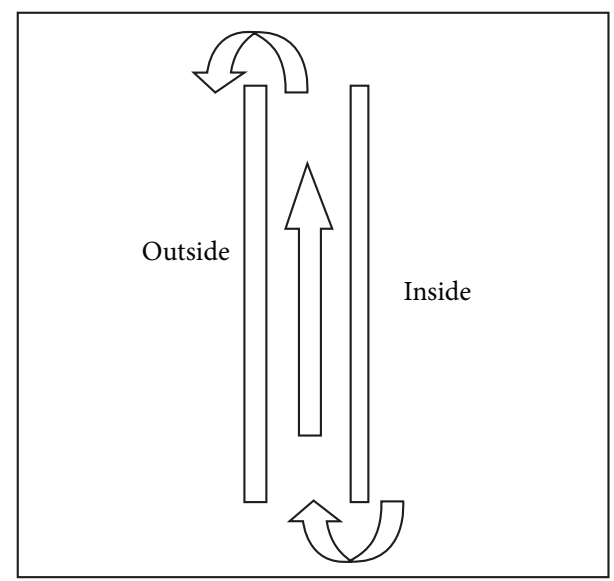

FIGURE 6: The schematic diagram of exhaust air in the north of DSF.

to outdoor environment (as shown in Figure 6). The exhaust whose temperature is close to the indoor temperature has a preheating effect on the ventilated cavity, and so to some degree, the effect reduces the heat loss through DSF to the outside and decreases the indoor air conditioning load which causess the decrease of air conditioning energy consumption through DSF [10].

4.1. Scheme Design of Gas Circulation Way Simulation. From the analysis above, it is known that orientation and air distribution mode have an important influence on the thermal performance of the DSF. In the case of different orientations, the operational mode of the DSF will be different because of the solar radiation; while in the case of the same orientation, it is apparent that there are large distinctions between the thermal performances of the DSF with no air circulation and that with air circulation. Meanwhile the amount of air circulation to some degree influences the thermal performance of the DSF. The scheme design of the simulation is shown in Table 2.

4.2. The Numerical Simulation and Comparative Analysis about the DSF Air circulation in Winter. This section is the first experimental comparison of the gas cycle simulation program. Choose the climatic characteristics of Shenyang as a simulated external conditions at the moment of the winter

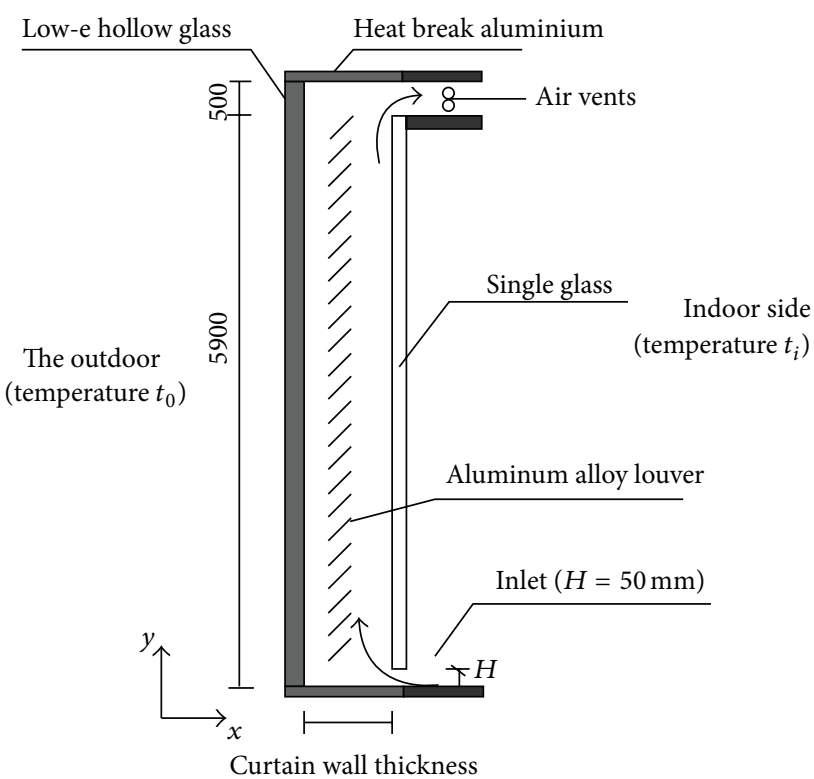

Figure 7: The inner loop of DSF.

solstice: we simulate south-facing DSF hourly from 7:00 am to 15:00 am. We calculate the cavity of DSF and the indoor temperature in order to increase the air circulation inside the south-facing DSF in winter.

(1) Geometric Model. This group of simulations is whether there is a simulation for air circulation. So when the simulation is going on, we need to build two sets of physical models. One group is no air circulation double-skin facade model, also known as a closed the DSF. It has already been built under the influence of regenerative cavity spacing on the thermal performance of the DSF construction, as shown in Figure 2. Another group is a model of the DSF with a group of air circulation, also known as the inner loop the DSF, as shown in Figure 7.

The simulation of two models using regenerative cavity spacing of $0.4 \mathrm{~m}$ glass curtain wall makes use of the geometry model cycle with a set of the DSF which is created by GAMBIT, as shown in Figure 8. The model and boundary conditions are selected as previously mentioned.

(2) The Analysis of Simulation Results. We still choose hourly simulation of major moment of the winter solstice, select the comparison of the hot channel spacing $0.4 \mathrm{~m}$ inner loop and airless cycle of the double skin-facde temperature and totally simulate 18 examples.

The simulation results are shown in Figures 9 and 10. By comparing, we can see that the DSF with the inner loop is more conducive to improving the indoor air temperature in the winter during the day, but during smaller solar radiation time or at night, the room temperature will lost quickly from the inside out. However, in the winter night, no air circulation double-skin glass curtain wall is more conducive to the holding of the indoor temperature. Double-skin glass curtain wall with an inner loop is virtually equivalent to an increase of the spacing of the heat storage cavity, which is 
TABle 1: The South solar radiation of winter solstice in Shenyang.

\begin{tabular}{lcccc}
\hline Time & $\begin{array}{c}\text { Dry-bulb } \\
\text { temperature } \\
\left({ }^{\circ} \mathrm{C}\right)\end{array}$ & $\begin{array}{c}\text { Wet bulb } \\
\text { temperature } \\
\left({ }^{\circ} \mathrm{C}\right)\end{array}$ & $\begin{array}{c}\text { Horizontal } \\
\text { radiation } \\
\text { intensity }\left(\mathrm{w} / \mathrm{m}^{2}\right)\end{array}$ & $\begin{array}{c}\text { South radiation } \\
\text { intensity }\left(\mathrm{w} / \mathrm{m}^{2}\right)\end{array}$ \\
\hline $7 \mathrm{am}$ & -2.6 & -5.4 & 132.99 & 370.73 \\
$8 \mathrm{am}$ & -2.1 & -5.2 & 280.12 & 524.48 \\
$9 \mathrm{am}$ & -1.4 & -4.7 & 403.44 & 643.98 \\
$10 \mathrm{am}$ & -0.6 & -4.3 & 219.05 & 109.53 \\
$11 \mathrm{am}$ & 0.0 & -4.0 & 220.19 & 110.10 \\
$12 \mathrm{am}$ & 0.2 & -4.0 & 410.32 & 650.53 \\
$1 \mathrm{pm}$ & -0.2 & -4.4 & 133.74 & 66.87 \\
$2 \mathrm{pm}$ & -1.4 & -5.2 & 66.12 & 33.06 \\
$3 \mathrm{pm}$ & -3.0 & -6.4 & 3.48 & 36.83 \\
\hline
\end{tabular}

TABLE 2: The simulation program of airflow movement.

\begin{tabular}{ll}
\hline $\begin{array}{l}\text { The first group: contrast } \\
\text { simulation with and } \\
\text { without air circulation }\end{array}$ & DSF without air circulation \\
& $\begin{array}{l}\text { Group 1 of double-skin façade } \\
\text { with air circulation }\end{array}$ \\
\hline $\begin{array}{l}\text { The second group: } \\
\text { contrast simulation with } \\
\begin{array}{l}\text { and without air } \\
\text { circulation }\end{array}\end{array}$ & $\begin{array}{l}\text { Group 1 of double-skin façade } \\
\text { with air circulation }\end{array}$ \\
\hline
\end{tabular}

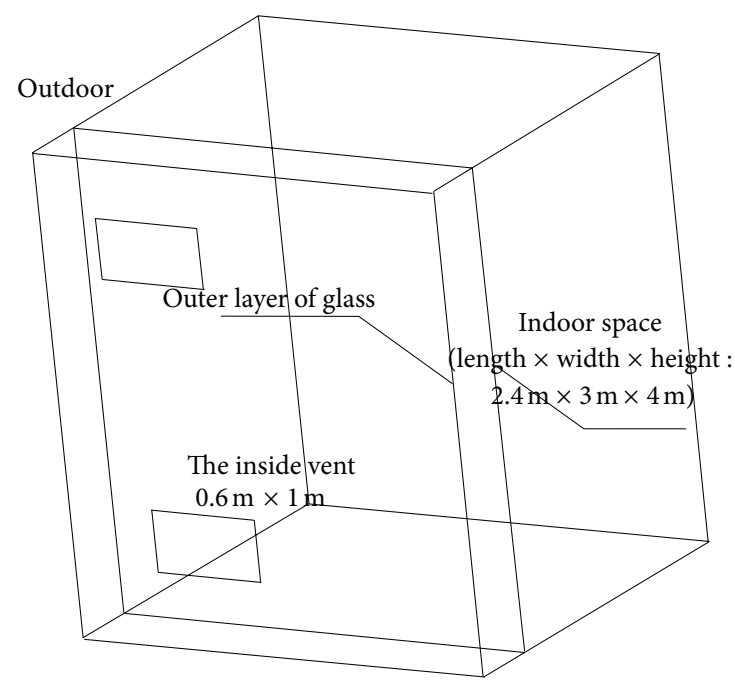

FIgURE 8: The structure of DSF which has one pair of inner loops.

not conducive to indoor delay insulation, which corroborated analog conclusions of the previous section from the side again. At night or solar radiation small moment, the small regenerative cavity spacing of the DSF is more conducive to hold the indoor temperature [11].

4.3. The Numerical Simulation and Comparative Analysis of the Amount of the DSF Air Circulation in Winter. The simulation of this section needs to build a geometric model of

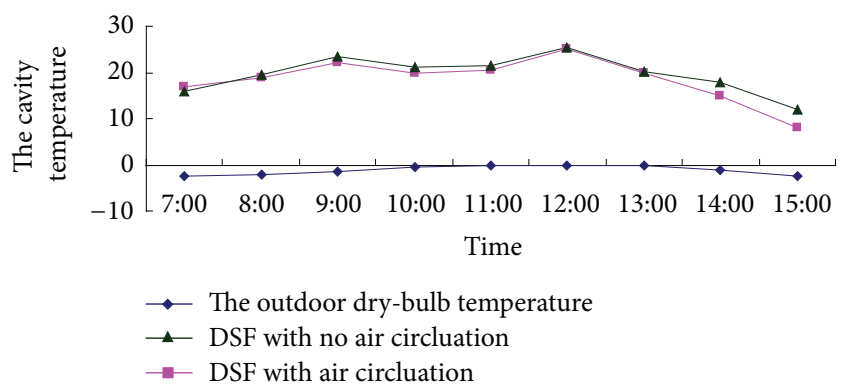

FIGURE 9: The contrast of interior temperature of DSF when the inner loop is set or not.

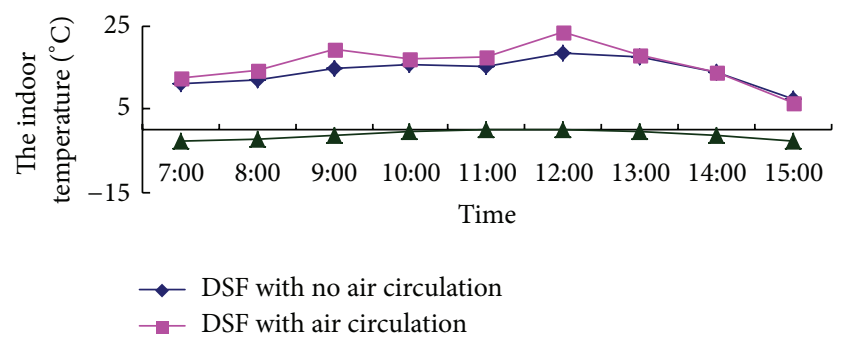

FIGURE 10: The contrast of indoor temperature when the inner loop is set or not.

two groups, one for a group of the air circulation mode of the DSF; this model has been constructed in a simulate analysis in the last section. For two sets of the air circulation mode a DSF geometry model is shown in Figure 11.

The choice of a model and the boundary conditions set as previously indicated, based on the simulation results shown in Figures 12 and 13, the analysis shows that the larger period of radiation in the winter sun, the set of air circulation is conducive to raise the average temperature in the room, with the increase in the amount of air circulation, the indoor temperature will be more improved. However, in a small period of solar radiation or at night, the air circulation does not have good insulation effect. It will speed up the heat transmission from the indoor to the outdoor, resulting in the decrease of room temperature rapidly. The greater the amount 


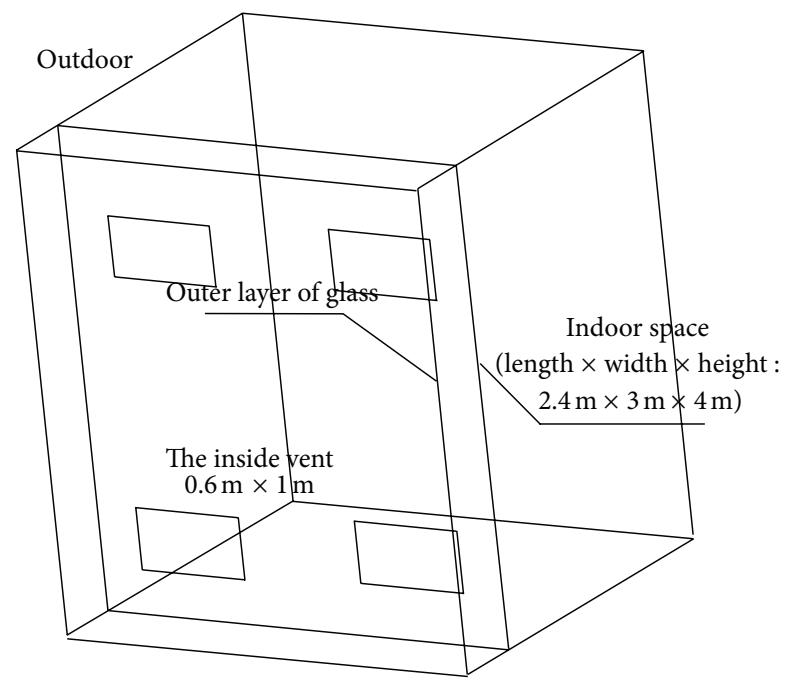

FIGURE 11: The structure of DSF which has two pairs of inner loop.

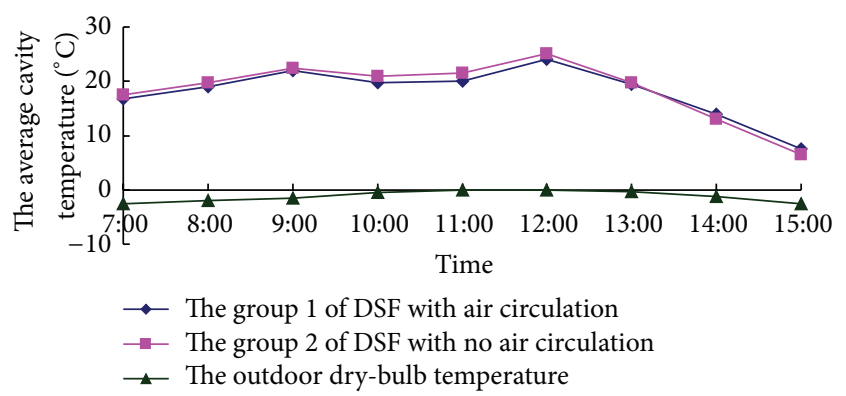

FIGURE 12: The contrast of interior temperature of DSF when the amount of airflow is changed.

TABLE 3: The heat transfer coefficient of DSF.

\begin{tabular}{llll}
\hline Cavity spacing $(\mathrm{mm})$ & 200 & 400 & 600 \\
\hline Heat transfer coefficient $\mathrm{w} / \mathrm{m}^{2} \cdot \mathrm{k}$ & 1.13 & 1.14 & 1.12 \\
\hline
\end{tabular}

of air circulation, the faster heat loss will be. So when solar radiation is small or at night, it is better to use the closed no-loop DSF [12], in order to facilitate the preservation room temperature and reduce indoor heat loss.

\section{DEST Numerical Simulations}

This section mainly uses the DEST energy analysis tool to simulate the energy consumption of the DSF in the case of different external structures and different building orientations [13]. Using front FLUENT simulation results, we can see that the major moment of the winter solstice, the temperature of the glass surface of the inner and outer layers of the DSF, Here first calculate the cavity width of $200 \mathrm{~mm}$, $400 \mathrm{~mm}, 600 \mathrm{~mm}$ South to the DSF [14], Substituting into the previously described heat transfer coefficient calculation formula. When the outdoor temperature is $2.1^{\circ} \mathrm{C}$, the solar radiation is $650 \mathrm{w} / \mathrm{m}^{2}$; the calculated results are shown in Table 3.

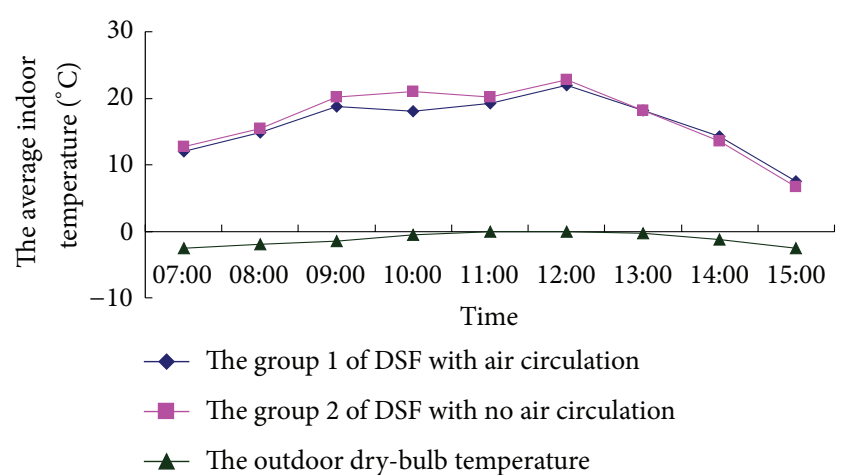

FIGURE 13: The contrast of indoor temperature when the amount of airflow is changed.

TABLE 4: The performance of wall.

\begin{tabular}{|c|c|c|}
\hline $\begin{array}{l}\text { External structure } \\
\text { coefficient type }\end{array}$ & $\begin{array}{l}\text { Heat transfer } \\
\left(\mathrm{w} / \mathrm{m}^{2} \cdot \mathrm{k}\right)\end{array}$ & Remark \\
\hline Concrete walls-Jane- 85 & 0.486 & $\begin{array}{l}20 \mathrm{~mm} \text { cement mortar }+ \\
200 \mathrm{~mm} \text { reinforced } \\
\text { concrete }+85 \mathrm{~mm} \\
\text { expanded perlite }+20 \mathrm{~mm} \\
\text { no cement fiberboard }\end{array}$ \\
\hline $\begin{array}{l}\text { Plating Low-e film } \\
\text { insulating glass curtain } \\
\text { wall }\end{array}$ & 2.1 & $\begin{array}{l}6 \text { (Low-e) }+9 \mathrm{~mm} \text { hollow } \\
+6 \text {, the solar } \\
\text { transmittance of } 33 \% \text {, and } \\
\text { the reflectance } 26 \%\end{array}$ \\
\hline $\begin{array}{l}\text { Double-skin glass } \\
\text { curtain wall }\end{array}$ & 1.14 & $\begin{array}{l}\text { Outer layer of } 8 \mathrm{~mm} \\
\text { tempered }+400 \mathrm{~mm} \\
\text { cavity + inner plated } \\
\text { Low-e membrane } 24 \mathrm{~mm} \\
\text { hollow glass }\end{array}$ \\
\hline
\end{tabular}

We can see from the table above that the cavity spacing has $200 \mathrm{~mm} \sim 600 \mathrm{~mm}$ range, the heat transfer coefficient of the DSF does not cause too much influence, and the cavity changes to only $0.8 \%$. Therefore, the effect of cavity spacing can be roughly ignored in the energy simulation.

5.1. Establishing the Model. By using the DEST energy analysis tool, we can make it more accurately on the office building energy simulation. The typical office building is a fivestory office building; main room types are ordinary office, reception room, office, leading the rest room, the bathroom, and the exhibition rooms. The established model shown in Figure 14 is three-dimensional model of the building generated by the DEST.

In order to investigate the power saving features of the DSF in cold regions, the DSF model is set as a typical office building with plated Low-e membrane hollow glass curtain wall, concrete wall-Jane- 85 for energy simulation. The characteristics of these a three-envelope structure are shown in Table 4, respectively.

The DSF in winter with no shade measures the hot channel is closed, no external circulation ventilation mode; to the external structure plated of Low-e membrane hollow glass 
TABLE 5: Building energy consumption when the external wall is changed.

\begin{tabular}{|c|c|c|c|}
\hline External structure type & $\begin{array}{l}\text { Concrete- } \\
\text { perlites-85 }\end{array}$ & $\begin{array}{c}\text { Low-e hollow } \\
\text { glass curtain } \\
\text { wall }\end{array}$ & The DSF \\
\hline Total annual heat load $(\mathrm{kw} \cdot \mathrm{h})$ & 411844.3 & 514763 & 439217.6 \\
\hline Total annual cooling $(\mathrm{kw} \cdot \mathrm{h})$ & 183457.6 & 409413.4 & 369627.6 \\
\hline Total annual load statistics $(\mathrm{kw} \cdot \mathrm{h})$ & 595301.9 & 924176.4 & 808845.2 \\
\hline Heating season heat load indicators $\left(\mathrm{w} / \mathrm{m}^{2}\right)$ & 27.5 & 34.3 & 29.3 \\
\hline $\begin{array}{l}\text { Air conditioning season's cold load indicators } \\
\left(\mathrm{w} / \mathrm{m}^{2}\right)\end{array}$ & 17.65 & 31.4 & 24.6 \\
\hline
\end{tabular}

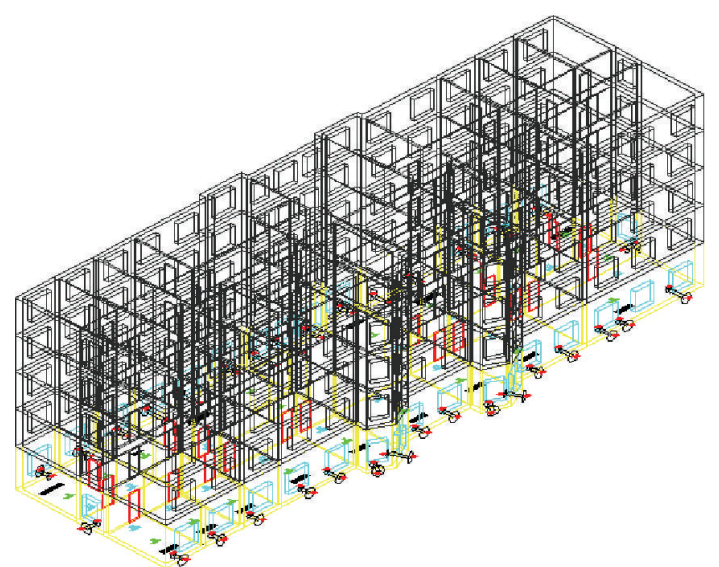

FIgURE 14: The building model generated by DEST.

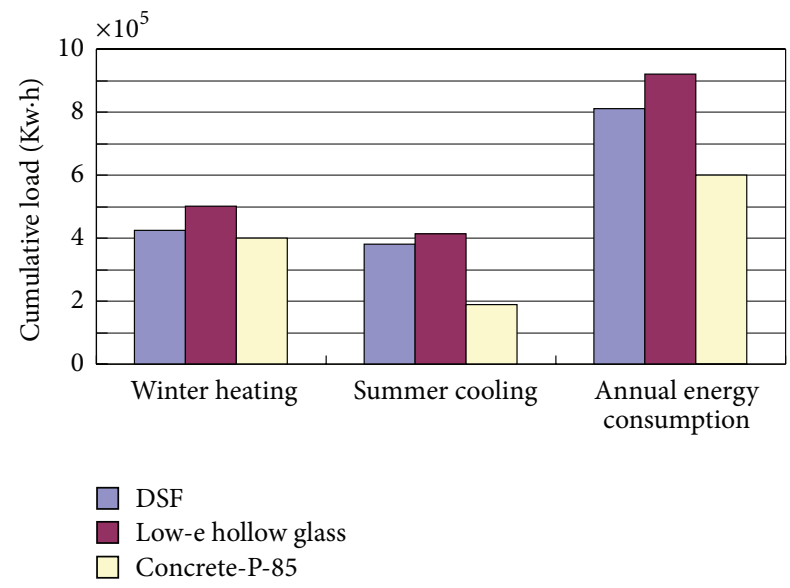

FIGURE 15: The contrast of energy consumption of the three kinds of external wall.

curtain wall and concrete wall plus steel outsider window, winter also using the no shading form [15].

5.2. External Structure of the Different Types of the DSF to the Influence of Building Energy Consumption. Doing DEST simulation for these three different external structure building models generates a load summary table about the building energy consumption as shown in Table 5.
Table 5 shows that the DSF has a better energy-saving effect than Low-e hollow glass curtain wall, about $17.2 \%$ energy saving higher than Low-e hollow glass curtain wall, and $6.2 \%$ higher than concrete-perlites- 85 energy consumption; the heating indicator is $29.3 \mathrm{w} / \mathrm{m}^{2}$ [16-18]. In summer cooling load, the DSF has $26.4 \%$ more energy consumption than the commonly used concrete-Perlites- 85 exterior wall more and $12.5 \%$ energy saving than plated Low-e hollow glass curtain wall [19].

Thus, the DSF will not play an outstanding energysaving role in the summer. The summer air conditioning cold indicators also showed a similar rule with the cooling load. This reflected that the energy-saving effect of the DSF is more suitable for the cold climate region; cold region has a shortterm summer with little requirements for air conditioning and a cold long winter with higher heating requirements $[20,21]$. Figure 15 obviously reflected the energy consumption of the DSF compared to other building envelopes in each season.

\subsection{Low-e Hollow Glass Curtain Wall of Different Building} toward to the Influence of Building Energy Consumption. Different building orientation has a great impact on the thermal performance of the DSF. In this paper, a typical five-story office building in cold regions is using for the construction of instance, simulate three external structure column in Table 5 respectively by the use of DEST, each toward of the DSF adopts closed without internal circulation of the DSF, a total of nine examples. Due to the area of the DSF and indoor space of the architecture model in the southward, northward, eastward and westward are all different, directly compare of annual cumulative load have no practical significance, therefore choose the plated Lowe hollow glass curtain wall and concrete-perlites-85 as [2224] the reference, compare the cumulative load. The specific simulation results are shown in Table 6.

Basis on the DSF, with reference to cooling and heating loads and annual cumulative load of the low-e hollow glass curtain wall and concrete-perlites-85 exterior wall, each toward lower energy efficiency ratio were calculated, the energy saving ratio tables are shown in Table 7.

Figures 16 and 17 were in the case of a different building toward the DSF total annual heating load being compared and the annual heating energy saving rate comparison. Normative provisions of the cold regions must consider the 
TABLE 6: The heat and cold load of the building when the building orientation is changed.

\begin{tabular}{lcccc}
\hline Building orientation & $\begin{array}{c}\text { External structure } \\
\text { (total annual kw } \cdot \mathrm{h})\end{array}$ & The DSF & $\begin{array}{c}\text { Low-e hollow glass } \\
\text { curtain wall }\end{array}$ & Concrete-perlites-85 \\
\hline \multirow{3}{*}{ Northward } & Heat load & 448910 & 484823 & 411844 \\
& Cooling load & 332721 & 422651 & 183458 \\
& Load statistics & 781632 & 907474 & 595302 \\
Westward & Heat load & 441909 & 483890 & 411844 \\
& Cooling load & 290313 & 404294 & 183458 \\
& Load statistics & 732222 & 888185 & 595302 \\
Southward & Heat load & 453853 & 482445 & 411844 \\
& Cooling load & 325993 & 442176 & 183458 \\
Load statistics & 779846 & 904621 & 595302 \\
Eastward & Heat load & 437379 & 481554 & 411844 \\
& Cooling load & 315083 & 413133 & 183458 \\
\hline
\end{tabular}

TABLE 7: The contrast of the ratio of energy conversion when the building orientation is changed.

\begin{tabular}{|c|c|c|c|}
\hline Building orientation & The energy saving ratio of the DSF (\%) & $\begin{array}{l}\text { Reference to Low-e } \\
\text { hollow glass curtain } \\
\text { wall }\end{array}$ & $\begin{array}{c}\text { Reference to } \\
\text { concrete-perlites- } 85\end{array}$ \\
\hline \multirow{3}{*}{ Northward } & Heat energy saving rate & 8.0 & -9.0 \\
\hline & Air conditioning energy saving rate & 21.3 & -44.9 \\
\hline & Annual energy saving rate & 16.1 & -31.3 \\
\hline \multirow{3}{*}{ Westward } & Heat energy saving rate & 9.5 & -7.3 \\
\hline & Air conditioning energy saving rate & 28.2 & -36.8 \\
\hline & Annual energy saving rate & 21.3 & -23.0 \\
\hline \multirow{3}{*}{ Southward } & Heat energy saving rate & 6.3 & -10.2 \\
\hline & Air conditioning energy saving rate & 26.3 & -43.7 \\
\hline & Annual energy saving rate & 16.0 & -31.0 \\
\hline \multirow{3}{*}{ Eastward } & Heat energy saving rate & 10.1 & -6.2 \\
\hline & Air conditioning energy saving rate & 23.7 & -41.8 \\
\hline & Annual energy saving rate & 18.9 & -26.4 \\
\hline
\end{tabular}

heating; air conditioning requirements generally may not be considered [25], and in this topic do comparative analysis mainly for winter heating energy consumption. Shown in Figure 16, the concrete-perlites-85 facades shows the energysaving sexual insulation exterior good performance; its energy consumption of winter heating is significantly lower than the DSF and Low-e hollow glass curtain wall regardless of the facing choice.

The DSF is lower than the low-e hollow glass curtain wall in the construction winter heating energy consumption in each toward, in the case of similar material; the DSF reveals strong advantage regarding the structure and function $[26,27]$. Refering to Figure 17 histogram, the energy saving rate descends from eastward, westward, and northward to southward.

\section{Conclusion}

This subject starting from climatic characteristic of the cold regions, combined the operation principle in the winter, getting the conclusion of the energy-saving design of the DSF adapting to cold regions.

(1) We simulate the different cavity spacing of the DSF by using the CFD software, found that during the solar radiation during the hot cavity spacing a large DSF with higher indoor temperature as well as empty cavity temperature in the winter daytime, solar radiation is small or at night time, the smaller cavity spacing of DSF has the better thermal insulation properties. 

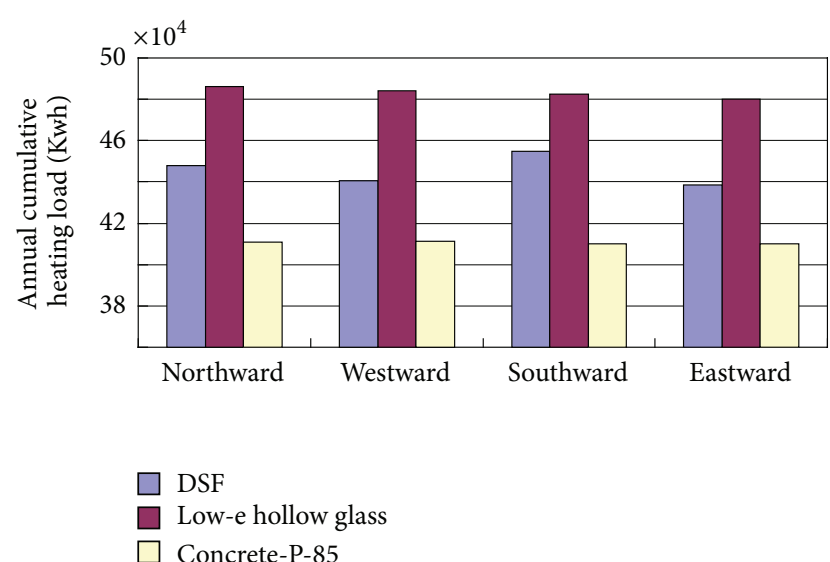

FIgURE 16: The contrast of heating load in one year when the building orientation is changed.

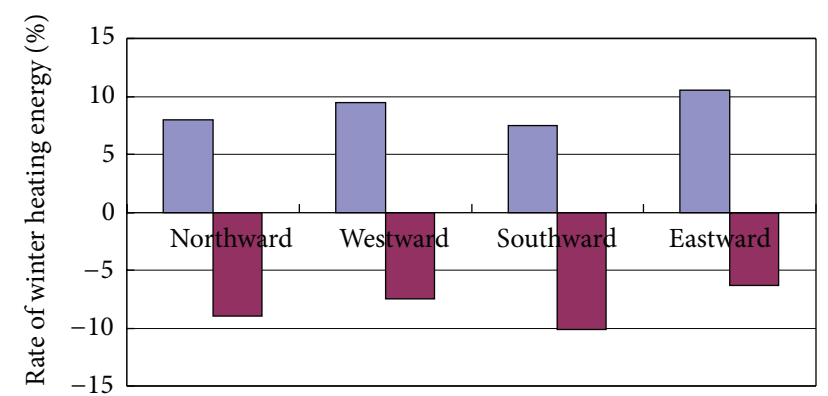

$\square$ Low-e hollow glass
$\square$ Concrete-perlites-85

FIGURE 17: The contrast of the ratio of heating in winter when the building orientation is changed.

(2) In general winter conditions use the circulation of the DSF, but the simulation found that winter daytime with air circulation of the DSF will get more favorable indoor environment. With the increase in the amount of air circulation, this phenomenon became more apparent. Closing the DSF could maintain indoor temperatures favor at night.

(3) Building energy simulation analysis, respectively, for the DSF, Low-e hollow glass curtain wall, and concrete-perlites-85, the simulation found that the double-skin glass curtain wall with a good energy saving effect in winter has a good energy saving effect in winter but in summer it cannot show outstanding energy-saving features; such energy-saving effect decides that it is suitable for the climate characteristics in cold regions with long cold winter and short summer.

(4) Total annual heating load calculation through four different buildings orientations shows that the energy saving rate of the DSF ranging from high to low is eastward, westward, northward, and southward.

\section{References}

[1] H. Zou, G. Wang, L. Guo, X. Wang, and H. Li, "The impact analysis on the building energy consumption of the windows in the sub-zero area," Journal of Shenyang Jianzhu University, vol. 25, no. 5, pp. 982-986, 2009.

[2] J. Von Grabe, "A prediction tool for the temperature field of double facades," Energy and Buildings, vol. 34, no. 9, pp. 891899, 2002.

[3] H. Manz and T. Frank, "Thermal simulation of buildings with double-skin façades," Energy and Buildings, vol. 37, no. 11, pp. 1114-1121, 2005.

[4] N. Ren and N. Yang, "The analysis of the double glass facades at north area," Journal of Shenyang Jianzhu University, no. 6, pp. 138-140, 2008

[5] J. J. Liu, Study on energy efficient design of double-skin facades [M.S. thesis], Tsinghua University, Beijing, China, 2006.

[6] X. Cen, J. Zhan, and S. Yang, "CFD simulation and optimization design of double skin façade," Acta Scientiarum Naturalium Universities Sunyatseni, no. 11, pp. 18-21, 2008.

[7] D. Saelens, J. Carmeliet, and H. Hens, "Energy performance assessment of multiple-skin facades," HVAC and R Research, vol. 9, no. 2, pp. 167-185, 2003.

[8] M. Liu and W. Long, "Exhaust air strategies of northward internal circulating DSF under winter working conditions in cold area," Building Science, vol. 25, no. 12, pp. 71-74, 2009.

[9] L. Peng, C. Liyong, and L. Wenjuan, "Research on ventilation performance of high-rise office building with doubleskin facade by wind tunnel tests," Heating Ventilating and Air Conditioning, vol. 34, no. 11, pp. 15-18, 2004.

[10] H. Poirazis and J. L. J. Rosenfeld, "Modeling of double skin facades-results obtained using WIS," Technical University of Denmark (DTU) Sags Rapport, vol. 23, no. 8, pp. 13-17, 2003.

[11] N. Du, The impact of different structure of double-skin glass facades to room heat environment [M.S. thesis], Chang'an University, Xi'an, China, 2007.

[12] M. Du, Study on thermal performance of double-skin facade of cold region [M.S. thesis], Tianjin University, Tianjin, China, 2007.

[13] J. Li, "Analysis and prospects of hot channel glass curtain wall," Shanxi Architecture, vol. 16, no. 4, pp. 10-13, 2002.

[14] Q. Wei, Dynamic analysis on double-skin facade using solar radiation [M.S. thesis], Chang'an University, Xi'an, China.

[15] Y. He, Experimental research and energy analysis of double glass curtain wall [M.S. thesis], Nanjing University of Science and Technology, Nanjing, China, 2010.

[16] B. Li, The research on climatic-active design strategy of building skin in hot-summer and cold-winter zone [M.S. thesis], Tsinghua University, Beijing, China, 2004.

[17] Y. Gao and L. Zhao, "Simulation and analysis of thermal performance of external respiration double skin facade," Heating Ventilating and Air Conditioning, vol. 37, no. 1, pp. 20-22, 2007.

[18] E. Djunaedy, J. Hensen, and M. Loomans, "Strategy for air flow simulation in building design center for building and systems," Technische Universities Eindhoven, vol. 31, no. 5, pp. 43-49, 2002.

[19] H. Jan and M. Wigginton, "Modeling and simulation of a double-skin facade system," Solar Energy, vol. 12, no. 6, pp. 115132, 2000.

[20] J. Von Grabe, "A prediction tool for the temperature field of double facades," Energy and Buildings, vol. 34, no. 9, pp. 891899, 2002. 
[21] E. Gratia and A. De Herde, "Natural ventilation in a double-skin facade," Energy and Buildings, vol. 36, no. 2, pp. 137-146, 2004.

[22] T. Pasquay, "Natural ventilation in high-rise buildings with double facades, saving or waste of energy," Energy and Buildings, vol. 36, no. 4, pp. 381-389, 2004.

[23] Z. Tian, S. K. Chou, and T. Y. Bong, "Building simulation: an overview of developments and information sources," Building and Environment, vol. 35, no. 4, pp. 347-361, 2000.

[24] D. Prasad and M. Snow, Designing With Solar Power, Images Publishing Group PTV, Australia, 2002.

[25] G. Augenbroe, "Trends in building simulation," Building and Environment, vol. 37, no. 8-9, pp. 891-902, 2002.

[26] A. J. B. Tadeu and D. M. R. Mateus, "Sound transmission through single, double and triple glazing. Experimental evaluation," Applied Acoustics, vol. 62, no. 3, pp. 307-325, 2001.

[27] A. Tzempelikos and A. K. Athienitis, "The impact of shading design and control on building cooling and lighting demand," Solar Energy, vol. 81, no. 3, pp. 369-382, 2007. 


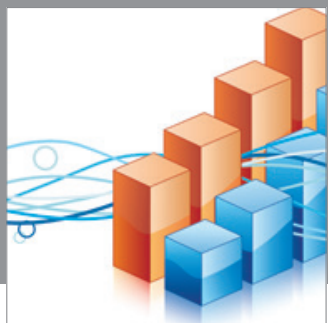

Advances in

Operations Research

mansans

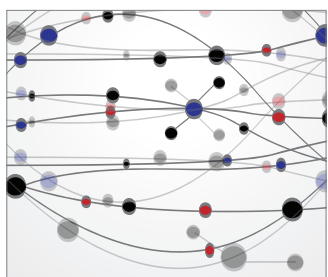

The Scientific World Journal
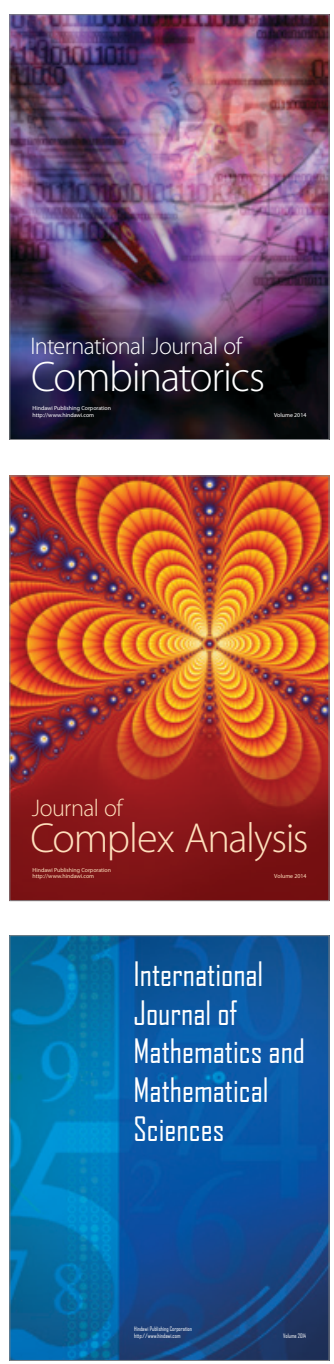
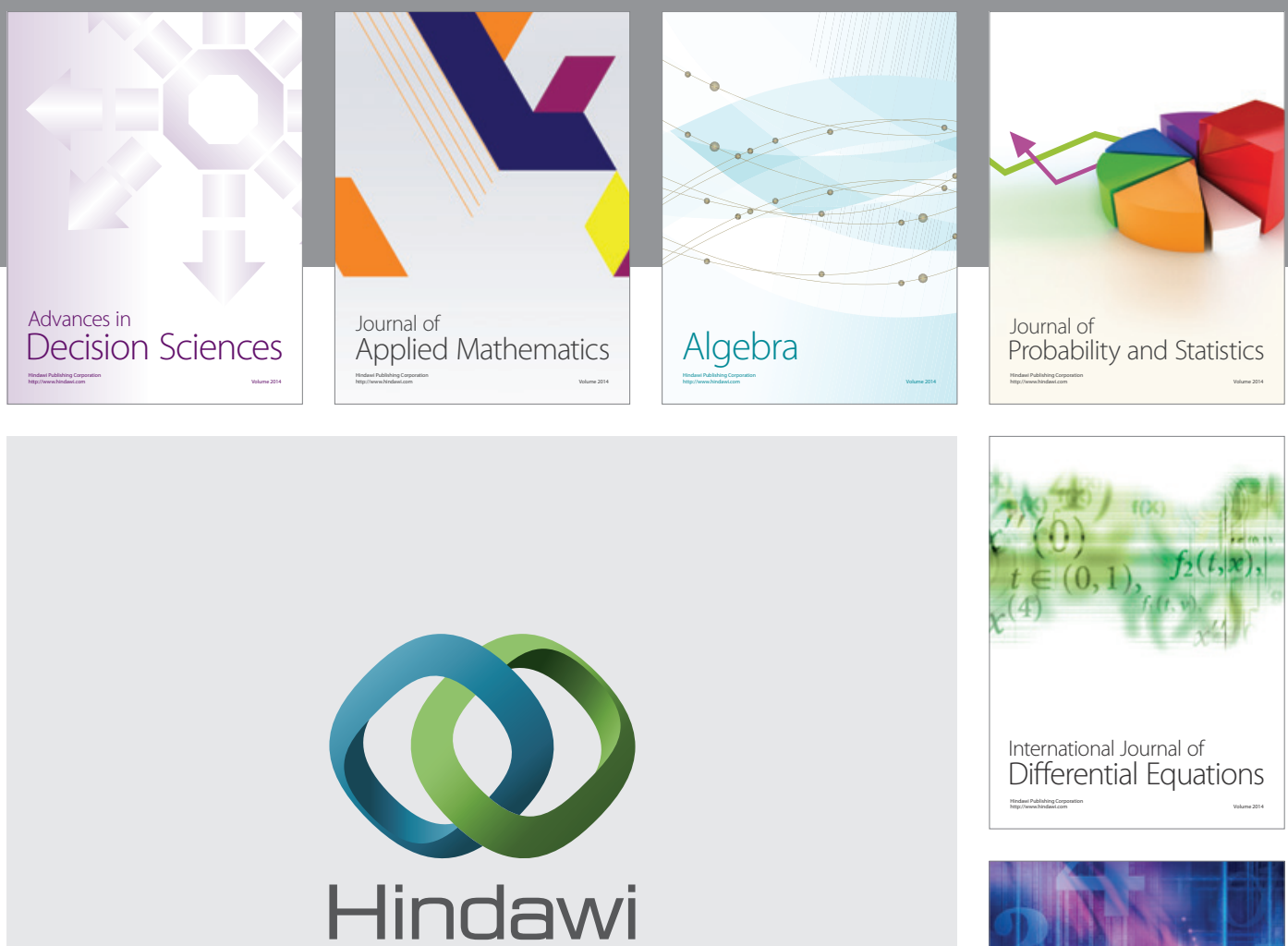

Submit your manuscripts at http://www.hindawi.com
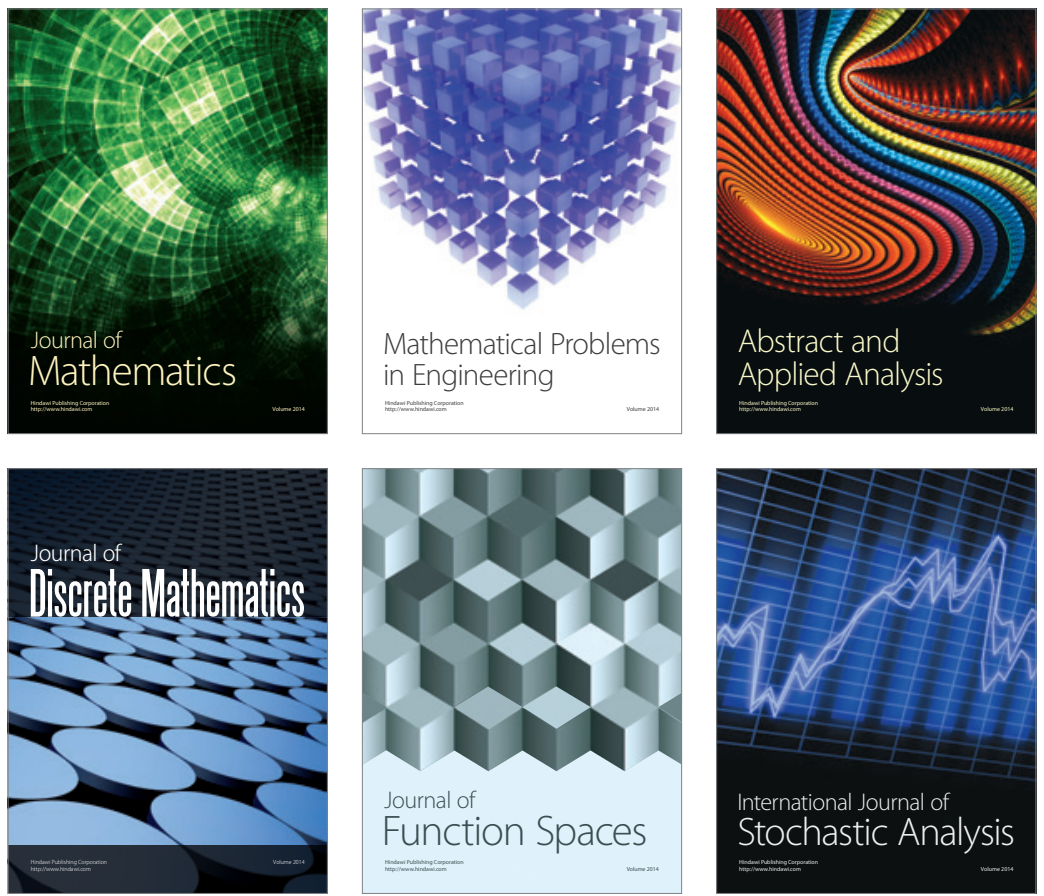

Journal of

Function Spaces

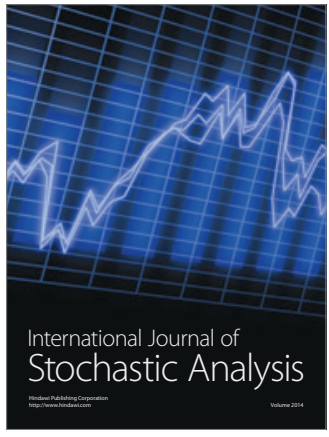

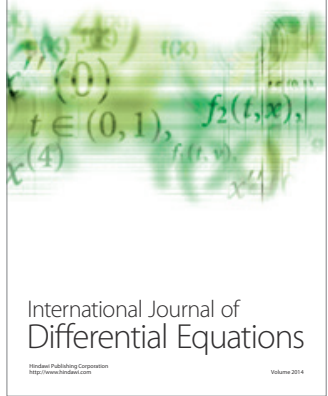
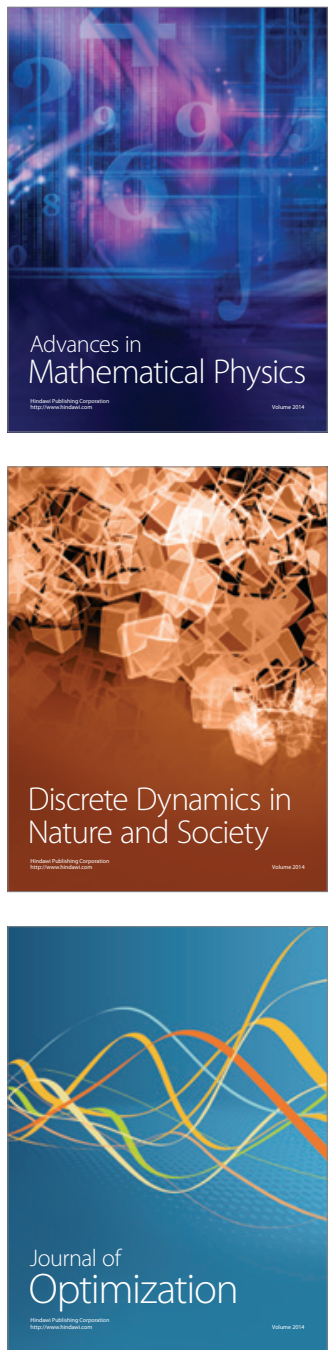